\title{
近赤外分光法によるデンプン糊化の解析
}

\author{
恩田 匠*・阿部英幸**・松永暁子*** \\ 小宮山美弘* $\cdot$ 河野澄夫**
}

\section{Analysis of Gelatinization of Starch by Near Infrared Spectroscopy}

\author{
Takumi OndA ${ }^{*}$, Hideyuki ABE**, Akiko MatsunaGA ${ }^{* * *}$, \\ Yoshihiro Komryama* and Sumio Kawano** \\ * The Yamanashi Industrial Technology Center, \\ 2094, Otsu-cho, Kofu-shi, Yamanashi 400 \\ ** National Food Research Institute, Ministry of Agriculture, Forestry and \\ Fisheries, 2-1-2, Kannondai, Tsukuba-shi, Ibaraki 305 \\ ${ }^{* * *}$ Ibaraki Women's Junior College, 960-2, Higashikinokura, \\ Naka-cho, Ibaraki 311-01
}

\begin{abstract}
Possibility of near infrared (NIR) spectroscopy for analysis of changes in structure of starch due to gelatinization, and determination of degree of gelatinization was investigated. Among second derivative NIR spectra of rice starch samples having different degrees of gelatinization, large deviations of spectra were observed at $1204,1368,1436,1700,1748,1784,1924,2088,2280,2320$ and $2348 \mathrm{~nm}$. Especially, spectra in the vicinity of 2100 and $2280 \mathrm{~nm}$ changed complexly according to progress of gelatinization. As a result of linear regression using second derivative absorbance values of NIR spectra and degrees of gelatinization by BAP method, high correlations were obtained in the vicinity of $1807 \mathrm{~nm}$ and $2095 \mathrm{~nm}$. In the vicinity of $1807 \mathrm{~nm}$, characteristic absorption band due to starch was not observed. The particle size could be one of reasons why high correlation was obtained, because high correlation existed between degree of gelatinization and particle size. In the vicinity of $2100 \mathrm{~nm}$, absorption due to starch and diffusion due to particle size overlapped. Then principal component (PC) analysis was applied to NIR spectra from $2040 \mathrm{~nm}$ to $2144 \mathrm{~nm}$ to reduce the effect of the diffusion on NIR spectra. Accurate linearity was obtained between second PC score and degree of gelatinization by BAP method. It was concluded that NIR spectroscopy has possibility to determine degree of gelatinization.

(Received Apr. 1, 1994)
\end{abstract}

米をはじめとするデンプン質食品の糊化および老化 は，味，消化性，物理的特性などの品質に密接に関連し た重要な要因の一つである.

デンプンの糊化抢よび老化に関する研究の歴史は古 く，多くの物理化学的，あるいは酵萃学的手法により， 多面的に研究(〉 7) が行われてきた。例えば，デンプンの
糊化度および老化度の評価 ${ }^{8)} は$ ，主として醉素法， X 線 回折法，熱分析法，アミログラフ法などにより行わ扎て きている，これらの方法には，迅速性に久ける，操作が 煩雑である，熟練を要するなどの問題点があった．また， これまでの研究では，デンプンの高次構造自体に未だ不 明な点もあり，糊化および老化の機椿はあまり解明され

\footnotetext{
*山梨県工業技術センター（宁400 山梨県甲府市大津町 2094）

**農林水産省食品総合研究所（干305 茨城県つくば市観音台 2-1-2）

*** 淡城県女子短期大学（宁311-01 茨城県那珂町果木倉 960-2）
} 
ていない.このため, デンプンの構造変化を検出するた めの新しい手法の開発・導入が期待されている.

近赤外分光法（以下，近赤外法という）は，迅速・簡 便性を特徴とし，今日まで主として食品中の化学成分の 定量に用いられてきたが，最近では水の状態分析”や夕 ンパク質の構造解析 ${ }^{10)}$ な゙の基礎研究にあ用いられ，そ の伈用範囲が拡大している，特に，水の状態分析では， 水素結合の状態解析に用いられている.デンプンに関し ては，糊化デンプンのスペクトル測定・分析 ${ }^{11)} か ゙$ 行われ ているが, 鹵属等に関する詳細な解析は行われていな w.

以上のことから，近赤外法により，デンプンの糊化お よび老化による構造变化を捉えることができれば，糊化 度および老化度の測定に有効なだけでなく，糊化および 老化現象の機構解明に有力な手段となることが考えられ る.

そこで本研究では，その焦点を糊化・老化のうち糊化 に絞り，デンプンの糊化度の近赤外法による測定の可能 性について検討した。

\section{実験材料および方法}

\section{1. 供試材料}

ウルチ米デンプン（島田化学社製）で，85\%メタノー ルを用いた熱抽出により脱脂処理したものを供試した.

\section{2. 糊化デンプンの調製}

デンプンの糊化処理は，均一な糊化デンプンを再現よ く得るためアミログラフ（ブラベンダー社製）を用いて 行った，すなっち，デンプンの $10 \%$ 水奬濁液を， $30^{\circ} \mathrm{C}$ らいくつかの異なる温度 $\left(30 \sim 100^{\circ} \mathrm{C}\right)$ まで，昇温速度

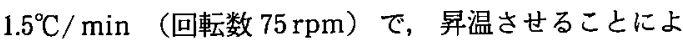
り，段階的に糊化度の異なるデンプン糊を調製した，得 られたデンプン糊は，3 倍容のエタノールを用いて，直 ちに脱水処理した。 さらにェタノールによる洗浄，吸引 ろ過を 3 回繰り返し，デンプンを粉末化した.この後， アセトン洗浄による脱エタノール処理を行い, 風乾し て，粉末デンプン試料（以下，糊化姏理デンプン試料と いう）とした.

\section{3. 近赤外吸収スペクトル測定}

糊化処理デンプン試料の近赤外吸収スペクトル（波長 領域：1100 2500 nm, 2nm ステップ）を近赤外分光装 置 (InfraAlyzer 500，ブラン・ルーベ社製) を用いて測 定した，測定には，粉体用標準セルを用いた。測定時の 実験室の温度は $25^{\circ} \mathrm{C}$, 相対湿度 $20 \% \mathrm{RH}$ 以下とした。 そ れぞれの試料は，シリカゲルが充塤されたデシケーター
内 $\left(25^{\circ} \mathrm{C}\right)$ において, 近赤外吸収スペクトル測定直前ま で一晚以上放置した

\section{4. 糊化度測定}

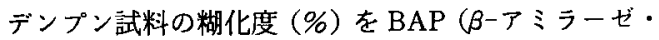
プルラナーゼ）法(2)により測定した。

\section{5. 粒度測定}

糊化処理デンプン試料の粒度をレーザー回折式粒度分 布測定装置（LS 100，コールター社製）を用いて測定し た，平均径 $(\mu \mathrm{m})$ を屯って粒度とした，糊化処理デンプ ン試料は，イソプロピルアルコールによく分散させて測 定した。

\section{6. 単回帰分析}

近赤外吸収スペクトルの単回帰分析は，近赤外分光装 置に付属の近赤外吸収スペクトル解析ソフトゥェアを用 いて行った.

スペクトル以外の単回帰分析は，表計算ソフトウェア Excel $4.0 \mathrm{~J}$ (for Macintosh，マイクロソフト社製) を用 いて行った.

\section{7. 主成分分析}

近赤外吸収スペクトルの主成分分析（以下，PCA とい う）は, BERTRAND ら ${ }^{11)}$ の開発した主成分分析ソフト ウェアを用いた。 また得られた主成分スコアを用いて， 主成分回帰分析を行った。

\section{実験結果および考察}

\section{1. 糊化処理デンプン試料の近赤外吸収スペクトル} 糊化度が段階的に異なる糊化処理デンプン試料 13 点 の近赤外吸収スペクトルを測定した。

糊化処理デンプン試料の近赤外吸収スペクトルは，粒 度などの物理的な影響を受け，試料によりべースライン が上下にシフトした。 そこで，近赤外吸収スペクトルを 2 次微分処理（微分条件： segment；12, gap；0）して, 吸収ピークの変化を調べた（Fig. 1). その結果, 各試料 間で $1204,1368,1436,1700,1748,1784,1924$, $2088 ， 2280,2320$ および $2348 \mathrm{~nm}$ 近傍の吸光度の変動 (分散) が大きいことが明らかになった，1924nmの吸 収は水の O-H 基に，その他のピークは主としてデンプ ンの $\mathrm{O}-\mathrm{H}$ 基あるいは $\mathrm{C}-\mathrm{H}$ 基に由来する吸収(3) である と考えられた。 2100 および $2280 \mathrm{~nm}$ 近傍の吸収ピーク は，糊化度が進むにつれて後述するように非常に複雑な 変化を示した. この 2 つの波長帯には, デンプンの特徽 的な吸収が存在することから，糊化による構造変化に関 連する情報が反映しているすのと考えられた． $2100 \mathrm{~nm}$ 近傍において，生デンプンでは, $2070 \mathrm{~nm}$ に吸収ピーク 


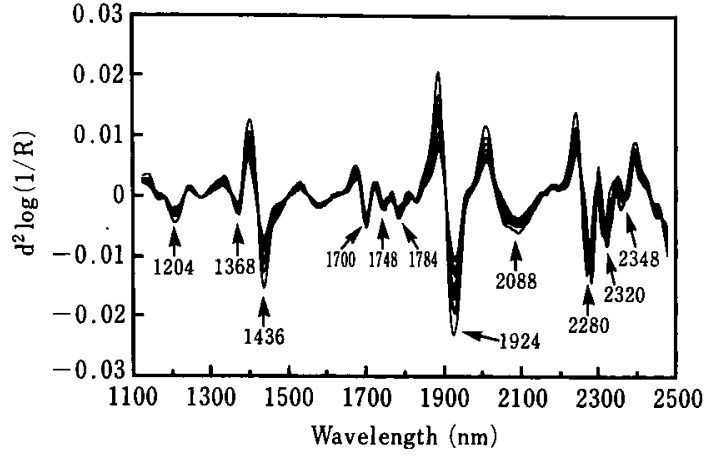

Fig. 1 Second derivative near infrared spectra of rice starch samples having different degrees of gelatinization

Numbers in the figure indicate wavelength (nm) at which large variance of absorbance exist.

の極小值が存在し，2120 nmにも吸収が存在するが，糊 化処理温度が $56^{\circ} \mathrm{C}$ の試料までは $2070 \mathrm{~nm}$ の吸収が徐々 に消失し，2090 nm の吸収が極小值になった，つぎに， $56^{\circ} \mathrm{C}$ から $100^{\circ} \mathrm{C}$ まで試料では $2090 \mathrm{~nm}$ の吸収が増大 し，かつ $2070 \mathrm{~nm}$ 付近の吸収む再び増大した（FIg. 2) デンプンの近赤外吸収スペクトルの $2100 \mathrm{~nm}$ 近傍には, $2090 お よ ひ ゙ 2100 \mathrm{~nm}$ の 2つの吸収帯が重なって存在し ており ${ }^{13)}$, 上述したスペクトルの複雑な変動は，2つの 吸収の変化之密接な関連があるものと考えられた。一 方, $2280 \mathrm{~nm}$ 近傍では, $2280 \mathrm{~nm}$ の吸収が $56^{\circ} \mathrm{C}$ ま゙の試 料で増大し, $56^{\circ} \mathrm{Cから} 66^{\circ} \mathrm{C}$ までの試料で咸少した（Fig. 3A). $66^{\circ} \mathrm{C}$ か $70^{\circ} \mathrm{C}$ までの試料では, 吸収が $2280 \mathrm{~nm}$ か ら $2270 \mathrm{~nm}$ にシフトした後, $100^{\circ} \mathrm{C}$ 試料で吸収が再び $2280 \mathrm{~nm}$ にシフトするといった與味ある変化を示した (Fig. 3B). $2280 \mathrm{~nm}$ 近傍にも2つの吸収のピークの存 在が示唆された。なお, 図表には示さないが, ほぼ同様 な変化が $2320 \mathrm{~nm}$ 近傍においても観察された。

\section{2. 近赤外吸収スペクトルの単回㷌分析}

近赤外吸収スペクトルは，試料によりベースラインが 上下にシフトしたため, 単回㴆分析には 2 次微分処理し たスペクトルを用いた。 まずBAP 法により得られた糊 化度 $(\%)$ を目的变数として，吸光度の 2 次微分值を説 明変数亡して単回州分析を行い, Fig. 4 の結果を得た. 同図は各波長毎に相関係数をプロットしたもの（以下， 相関スペクトルという）である．2次微分スペクトルに おいては, 成分の増加とともに吸光度の 2 次微分と絶対

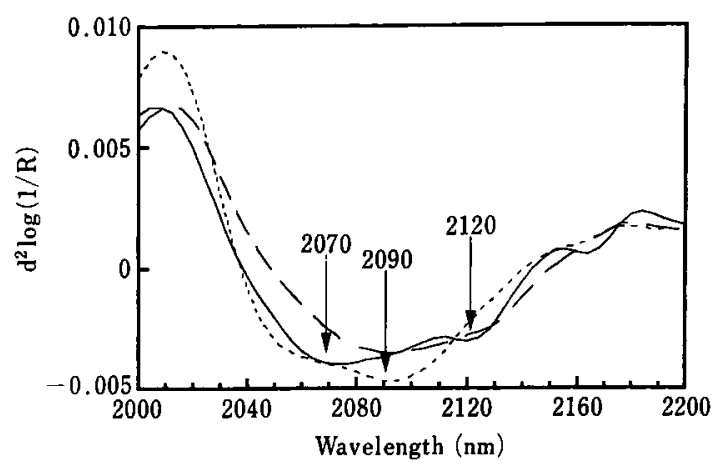

Fig. 2 Second derivative near infrared spectra of starch samples in wavelength region from $2000 \mathrm{~nm}$ to $2200 \mathrm{~nm}$

Symbols :- - raw starch (gelatinization treat-ment to $25^{\circ} \mathrm{C}$ ); -- , gelatinization treatment to $56^{\circ} \mathrm{C} ;---$, gelatinization treatment to $100^{\circ} \mathrm{C}$.

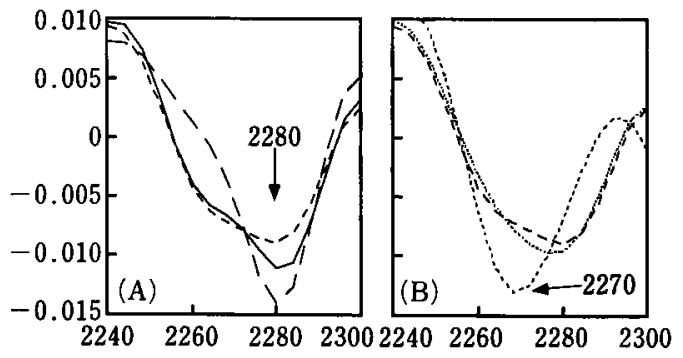

Fig. 3 Second derivative near infrared spectra of starch samples in wavelength region from $2240 \mathrm{~nm}$ to $2300 \mathrm{~nm}$

(A) gelatinization treatment from $25^{\circ} \mathrm{C}$ to $66^{\circ} \mathrm{C}$.

(B) gelatinization treatment from $66^{\circ} \mathrm{C}$ to $100^{\circ} \mathrm{C}$.

Symbols : (A) $56^{\circ} \mathrm{C} ;---$, to $66^{\circ} \mathrm{C} ;(\mathrm{B})---$, to $66^{\circ} \mathrm{C} ;----$, to $70^{\circ} \mathrm{C} ; \cdots \cdots$, , to $100^{\circ} \mathrm{C}$

值が負の方向に大きくなるため，その相関係数はマイナ スでなければならない. また相関スペクトルのピークの うち，その形状が丸みを帯びたものが再現よく相関の得 られる波長と判断できる.Fig. 4 では，1220，1807およ び $2095 \mathrm{~nm}$ で高い正の相関が得られた。 1220 および $2095 \mathrm{~nm}$ 近傍にはデンプンの吸収が認められたが,

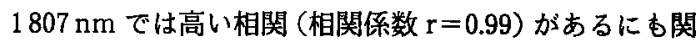
わらず，明膫な吸収は観察できなかった，このことから， 


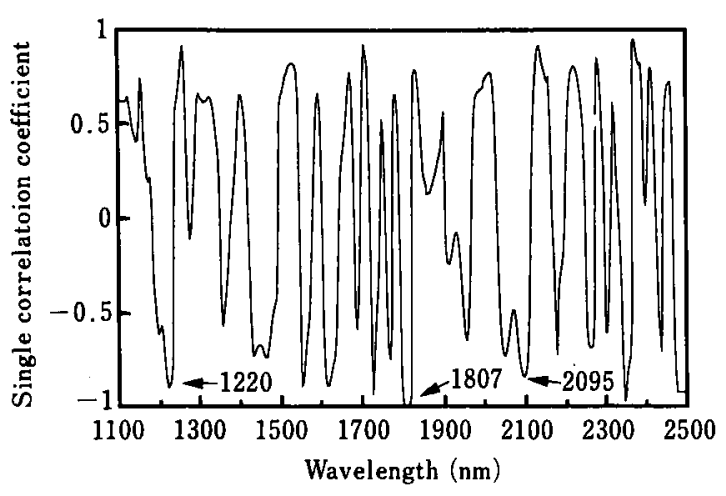

Fig. 4 Spectrum of single correlation coefficient between $d^{2} \log (1 / R)$ and degree of gelatinization

$1807 \mathrm{~nm}$ において高い相関係数が得られた原因は，糊化 度に関連した別の要因，例えば糊化デンプン試料の粒度 （デンプン粒の大きさ）などの物理的な要因に基づくも のと考えられた．そこで，糊化デンプン試料の粒度 $(\mu \mathrm{m})$ を目的变数として，糊化度の場合と同様に 2 次微 分した近赤外吸収スペクトルとの単回帰分析を行った。 その結果, 糊化度の場合之ほぼ同様の相関スペクトルが 得られた (Fig. 5)。 また糊化度と粒度との間には，比較 的高い相関性 $(r=0.96)$ が認められた。このことは，水 を加えて加熱する糊化処理によりデンプンの結晶状態の 崩壊が進み，糊化度が進むにつれて，膨潤したデンプン 粒の粒度が大きくなったことを意味している，以上のこ とから、デンプンの吸収が存在しない $1807 \mathrm{~nm}$ で高い 相関が示された実験結果は，その原因の 1 つとして近赤 外吸収スペクトルに影響を及ぼす粒度等の物理的要因に 基づくあのと推察された，一方，2095 $\mathrm{nm}$ 近傍はデンプ ンの主要な吸収帯であることから，糊化に伴うデンプン の構造変化を捉えている可能性が高い，しかしながら， 上述したようにこの波長帯においてあ粒度等の影響が及 んでおり，2095 nm で高い相関が得られたのは，デンプ ンの構造变化によるあのか，あるいは粒度などの物理的 影響によるものかの判断が困難である。そこで，2100 $\mathrm{nm}$ 近傍のスペクトルデータの主成分分析を行うことに より，情報の分離を行った。

\section{3. 近赤外吸収スペクトルの主成分分析（PCA）}

$2100 \mathrm{~nm}$ 近傍 $(2040 \sim 2144 \mathrm{~nm})$ の吸光度の 2 次微分 值をむとにPCA を行ったところ，得られた第 2 主成分 スコアと糊化度との間に最も明瞭な直線性 $(\mathrm{r}=0.98)$ が 認められた。 (Fig.6)。一般にPCA では，測定対象物の

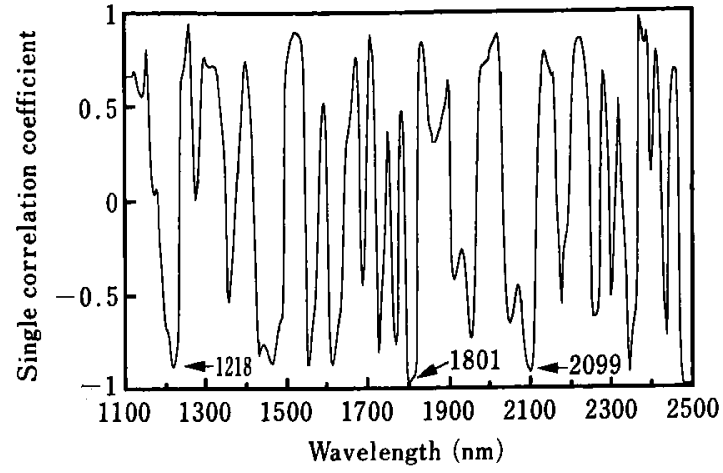

Fig. 5 Spectrum of single correlation coefficient between $d^{2} \log (1 / R)$ and particle size of starch

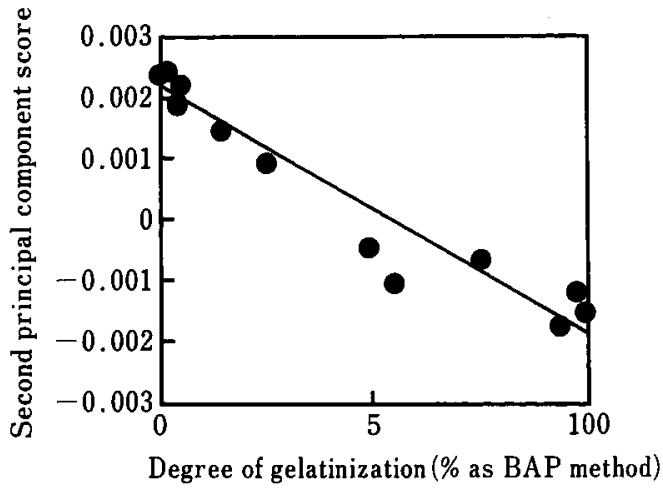

Fig. 6 Relationship between degrees of gelatinization by BAP method and second principal component scores

Principal component analysis was performed on spectrum in wavelength region from 2040 $\mathrm{nm}$ to $2144 \mathrm{~nm}$

物理的な特性による近赤外吸収スベクトルの変動が大き い場合,これらの物理的特性や/イズが主に第 1 主成分 に，それ以外の潜在的な情報は第 2 主成分以下に集約さ れる. 第 1 主成分と第 2 主成分の固有べクトルの “重み (loading weight)" を調べたところ (Fig. 7)，第 1 主成 分では変化が認められず，粒度などの物理的な影響を捉 えているものと考えた，第 2 主成分の “重み”には，2 $100 \mathrm{~nm} に+・$ 一の変曲点が存在し，デンプンの $\mathrm{O}-\mathrm{H}$ 基 の情報を捉えていることが推察された。このことによ り，PCAを行うことにより，近赤外吸収スペクトルか らデンプンの構造変化に付随した間接的要因による影 


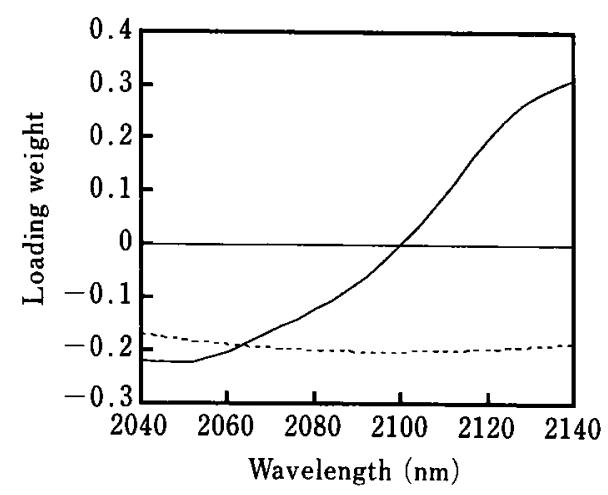

Fig. 7 Spectra of loading weights of first and second principal component

Symbols : …..., first principal component;

- second principal component.

響を除き，糊化に伴うデンプンの構造変化に直接関連し た情報のみを抽出することができたすのと考えられた．

以上のことから，近赤外法により，糊化処理したデン プンの糊化度を計測できることが明らかになった。

\section{要 約}

デンプンの糊化による構造変化および糊化度の近赤外 法による計測についで検討を行い，以下の結果を得た．

(1) 糊化度の異なるデンプンの近赤外吸収スペクトル を調べたところ，1204，1368，1436，1700，1748，1784， 1924，2088，2280，2320 および $2348 \mathrm{~nm}$ 近傍の吸収度 の変動（分散）が大きかった。特に，2088 および 2280 $\mathrm{nm}$ 近傍のスペクトルは，糊化の進行に伴い複雑な变動 を示した。

（2） BAP 法の糊化度またはデンプンの粒度をそれ ぞれ目的変数とし，吸光度の 2 次微分值を説明变数とす る回帰分析を行ったところ，ともに 1807 および 2095 $\mathrm{nm}$ で高い相関が得られた。

(3) デンプンの吸収帯が存在しないことから，1807 $\mathrm{nm}$ における高い相関は，その原因の 1 つとして粒度な よ゙の物理的な要因に基づくすのと考えられた。

(4) 糊化度之粒度の間には，高い正の相関 $(\mathrm{r}=0.96)$ が認められた．糊化度が進むにつれて，デンプンの粒子 が大きくなるものと考元られた。
(5) $2100 \mathrm{~nm}$ 近傍のスペクトルデー夕は，粒度などの 情報とデンプンの構造変化の情報が重なっていることか ら，主成分分析により，情報の分離を行ったところ，得 られた第 2 主成分スコアと糊化度との間に高い直線性 $(\mathrm{r}=0.98)$ が認められた.

以上のことから，近赤外法によりデンプンの糊化度を 計測できることが明らかとなった。

デンプンに関する一般的な実験操作にあたり，貴重な ご助言を頂きました農林水産省食品総合研究所炭水化物 室長小林昭一博士に謝意を表します，また，アミログラ フによるデンプンの糊化処理および粒度測定において, 技術的ご指導を頂いた同研究所穀類利用研究室長今井徹 博士に感謝します。

\section{文献}

1）檜作 進: 食品工業，12，1下，89（1969）.

2）檜作 進: 食品工業，12，2下，83（1969）。

3）二國二郎：調理科学，2，6（1969）.

4）貝沼圭二：New Food lndustry, 28，49 (1986).

5）不破英次：調理科学，20，2（1987）.

6) ScHOCH T.J.: 激粉科学, 14, 15 (1967).

6) LEACH, H.W. : Starch ; Chemistry and Technology, 2nd ed., edited by WHISTER, R.L., BEMILLER, J.N. and PAschall, F.R., (Academic Press, London) (1984).

8）中村道徳・貝沼圭二：汼粉・関連糖質実験法， (学会出版センター, 東京) p.163 (1986).

9) Iwamoto, M., Uozumi, J. and Nishinari, K.: Near Infrared Diffuse Refrectance/Transmittance Spectroscopy, edited by HoLlo, J., KAFFKA, K.J. and GonCZY, J.L., p. 3 (1987).

10) KamishikiRYo-Yamashita, H., Tatara, M., TAKamuRA H. and Matoba T.: Nippon Shokuhin Kogyo Gakkaishi, 41, 65 (1994).

11) Bertrand, D. and Scotter, N.G. : Appied Spectrosopy, 46, 1420 (1992).

12）貝沼圭二・松永兟子・板川正秀・小林昭一：泚粉 化学, 28, 235 (1981).

13) Osborne, B.G. and FEARn, T. : Near Infrared Spectroscopy in Food Analysis (Longman Scientific Technical, New York), p. 28 (1986).

(平成 6 年 4 月 1 日受理) 